\title{
Field Experiments With Polaris as a Chemical Ripener of Sugarcane in Puerto Rico, 1971-72
}

\author{
George Samuels and A. Vélez-Ramos²
}

\begin{abstract}
Polaris, [N, N-bis (phosphonomethyl) glycine], was evaluated as a chemical ripener of sugarcane in small, replicated field plots and commercial-scale trials to determine optimal rates and time of application. When used early in the harvest season (December-January) in a field-plot experiment, Polaris at $2.24,4.48$, and $6.72 \mathrm{~kg} / \mathrm{ha}$ at 6 weeks after application gave significant increases in sucrose-percent-cane over the untreated control. In addition, $6.72 \mathrm{~kg} / \mathrm{ha}$ produced significant increases in sucrose over $2.24 \mathrm{~kg} / \mathrm{ha}$. At 8 weeks after application, the $6.72 \mathrm{~kg} /$ ha rate showed significant increases in sucrose over the control. For late harvest season application (May-June), Polaris at $6.72 \mathrm{~kg} / \mathrm{ha}$ significantly prevented decreases in sucrose at 2 and 4 weeks, but not at 6 or 8 weeks after application. With $6.72 \mathrm{~kg} / \mathrm{ha}$ of Polaris, the early-harvest application averaged a $12.9 \%$ increase in sucrose over control (10.74 vs 9.51) as compared to $7.3 \%$ for the late-harvest application (10.44 vs 9.73$)$.

Commercial-scale trials used $3.36 \mathrm{~kg} / \mathrm{ha}$ of Polaris by airplane on test sites on the humid north coast and irrigated southern coast. A significant response was found for the combined north coast trials at 4 weeks after application, with sucrose increases ranging from 9 to $15 \%$ over the controls.
\end{abstract}

\section{INTRODUCTION}

Puerto Rico offers a varied set of climate and soil conditions for ripening sugarcane. The normal harvest season of January to June is preceded and terminated by months of high temperatures and rainfall. The sucrose content of the cane during the season shows lower values at the beginning and the end with a relatively sharp peak in April. Low sucrose values at the beginning of the harvest season (January-February) are primarily associated with the use of immature cane that has not, as yet, fully ripened because of high moisture content from the autumn rains and residual soil nitrogen. In the middle of the harvest season (March-April), the processes of natural ripening should be operating by virtue of depleted soil moisture and nitrogen, and lower temperatures, giving rise to higher sucrose levels in the cane. At the end of the harvest season (May-June), spring rains and increasing temperatures present conditions fåvorable to resumption of growth and a corresponding depletion of sucrose.

With the mechanization of the sugarcane harvest in Puerto Rico, attention has been given to possible use of chemicals to enhance ripening of sugarcane, and to improve the synchronization of peak quality

${ }^{1}$ Manuscript submitted to the Editorial Board July 6, 1976.

${ }^{2}$ Agronomist and Assistant Agronomist, Agricultural Experiment Station, University of Puerto Rico, Mayagüez Campus, Río Piedras, P. R. 
with scheduled harvest operations. Recent reviews of ripener literature $(1,10,12)$ show inconsistent responses to all materials except Polaris ${ }^{3}$, [N, N-bis (phosphonomethyl)glycine]. Favorable responses are reported from east Asia, Queensland, Hawaii, and the northern Caribbean region $(3-6,11)$.

Initially tested in Puerto Rico in 1970 as C. P. 41845, Polaris proved superior to seven chemical compounds evaluated in 13 field experiments (8). Greenhouse experiments have shown a Polaris potential to maintain, or moderately increase, ripening activity under cultural conditions favoring increased growth rather than quality improvement (2).

The present report gives the results of field experiments in 1971-72 evaluating Polaris ripening activity at the beginning and end of the harvest season using field-plot and commercial-scale trials.

\section{METHODS}

\section{FIELD-PLOT TESTS}

Experiments were initiated at the Isabela Substation to evaluate Polaris as a sugarcane ripener at the beginning (December) and end (June) of the harvest season. The rates of material applied and other data are given in table 1.

Each experiment had four treatments replicated six times in a complete-block design. The plot consisted of six rows spaced $1.53 \mathrm{~m}$ and 6.71 $\mathrm{m}$ long with a $1.53 \mathrm{~m}$ pathway separating the ends of the plots. Effects of spray drift were minimized by leaving guard spaces of at least $3.05 \mathrm{~m}$ (or two unsprayed interrows) between plots and spraying in early morning. The spray was applied above the cane canopy through a single wideangle nozzle mounted on a long lance connected to a back-pack sprayer.

The Polaris formulation, a water soluble powder containing $85 \%$ active ingredient supplied by Monsanto Agricultural Products, St. Louis, Missouri, was used at rates of $2.24,4.43$, and $6.72 \mathrm{~kg} / \mathrm{ha}$ in 467 liter/ha of water. All solutions included $0.5 \%$ of the wetting agent Chevron X-77 (alkylaryl polyxyethyleneglycol). This volume of spray required two passes over the same rows.

The two fully-sprayed center rows were used for sampling, taking 15 whole canes minus tops per plot. The cane samples were passed through a silage-chopper, and a representative $500 \mathrm{~g}$ sample (collected with a baffle) was rapidly deep-frozen. The frozen samples were later analyzed by the pol ratio method (7) to obtain sucrose-percent-cane values.

3 Trade names are used in this publication solely for the purpose of providing specific information. Mention of a trade name does not constitute a guarantee or warranty of equipment or materials by the Agricultural Experiment Station of the University of Puerto Rico or an endorsement over other equipment or materials not mentioned. 


\section{COMMERCIAL-SCALE TRIALS}

With support of a research grant from the Monsanto Agricultural Products Company, trials were initiated to evaluate Polaris under actual commercial conditions. The recommended dosage of $3.36 \mathrm{~kg} / \mathrm{ha}$ in 74 liters of water was applied by airplane at the beginning of the harvest season. Test sites at Central Cambalache and Coloso represented the north, Central Igualdad the west, and Mercedita the south coast. The first three areas normally receive sufficient rainfall; the last requires irrigation. Dates of application are given in table 1.

Sprayed areas averaged 1.2 ha or more while the remainder of the fields served as controls. The ripener was applied before $0700 \mathrm{~h}$ when wind speed was below $16 \mathrm{~km} / \mathrm{h}$ to minimize drifting. Samples were taken for sugar analyses at preselected sites in sprayed and control portions of the field. At each sampling site, 15 whole canes minus tops were selected at random. The samples were processed as described for Field-Plot Tests.

Due to the importance of climatic influences on ripener response, pertinent rainfall and temperature data are summarized in table 2.

\section{RESULTS AND DISCUSSION}

FIELD-PLOT TESTS

Table 3 shows the ability of Polaris to enhance ripening for sugarcane harvested at the beginning and end of the harvest season. With Polaris applied at the beginning of the harvest season experiment (DecemberJanuary), at $2.24,4.48$, and $6.72 \mathrm{~kg} / \mathrm{ha}$ at 4 weeks after application the sucrose-percent-cane was higher than that of the untreated control. The increases reached significant levels at 6 weeks after application. At 8 weeks after application, sucrose-percent-cane in the control plots had risen substantially as natural ripening proceeded, so that only the 6.72 $\mathrm{kg} / \mathrm{ha}$ rate was significant.

For the end of the harvest season experiment (May-June), Polaris at $6.72 \mathrm{~kg} / \mathrm{ha}$ at 2 weeks after application had significantly higher sucrose percent cane values than the $2.24 \mathrm{~kg} / \mathrm{h}$ a and untreated control (table 3 ). At 4 weeks after application the $6.72 \mathrm{~kg} / \mathrm{ha}$ rate was still able to maintain a significant increase over the dropping sucrose-percent-cane values of the control, but not at 6 weeks after application. By 8 weeks after application the high rainfall and increasing temperatures (table 2) had caused the cane in the various treatments to drop in sucrose to a nonsignificant difference between all rates applied.

The seasonal application of Polaris indicated a superiority of early application over those given at the end of the season. The $6.72 \mathrm{~kg} / \mathrm{ha}$ Polaris rate averaged 1.23 units more sucrose percent cane than the 
TABLE 1.-Experimental sites and treatments of the Polaris sugarcane experiments

\begin{tabular}{|c|c|c|c|c|c|c|c|}
\hline \multirow{2}{*}{ Location } & \multirow{2}{*}{ Variety } & \multirow[b]{2}{*}{ Crop } & \multirow{2}{*}{$\begin{array}{l}\text { Time of } \\
\text { harvest }\end{array}$} & \multicolumn{3}{|c|}{ Application } & \multirow{2}{*}{$\begin{array}{l}\text { Time of sam- } \\
\text { pling after ap } \\
\text { plication }\end{array}$} \\
\hline & & & & Rate' $^{1}$ & Date & $\begin{array}{c}\text { Age of } \\
\text { cane }\end{array}$ & \\
\hline & & & & $\mathrm{Kg} / \mathrm{ha}$ (lb/acre) & & Months & Weeks \\
\hline Isabela ${ }^{2}$ & PR 980 & Ratoon & Early & $2.24,4.48,6.72(2,4,6)$ & $11-16-71$ & 9 & $4,6,8$ \\
\hline Cambalache & PR 980 & Ratoon & Early & $3.36(3)$ & 1-14-71 & 11 & $2,4,6,8$ \\
\hline Coloso & PR 1048 & Ratoon & Early & $3.36(3)$ & $2-3-71$ & 11 & $2,4,6,8$ \\
\hline Mercedita & PR 980 & Ratoon & Early & $3.36(3)$ & 2-11-71 & 10 & $2,4,6,8$ \\
\hline
\end{tabular}

${ }^{1}$ Active ingredients.

${ }^{2}$ Small-plot trials applied by back-pack sprayer; all others, commercial trials with Polaris applied by airplane. 
control for the early season application as compared to 0.71 units more for the end of the harvest application. This represented an increase of $12.9 \%$ and $7.3 \%$ for early and late season application, respectively. These findings are consistent with those of Frost and Selleck (4) in Louisiana.

It appears that Polaris has the ability to increase sucrose content at TABLe 2. - Weather data for Polaris sugarcane experiments

\begin{tabular}{|c|c|c|c|c|c|c|}
\hline \multirow[t]{2}{*}{ Location } & \multirow[t]{2}{*}{ Year } & \multicolumn{3}{|c|}{$\begin{array}{c}\text { Total rainfall in relation to date of } \\
\text { application. }\end{array}$} & \multicolumn{2}{|c|}{$\begin{array}{l}\text { Average of mean } \\
\text { daily temperature } \\
\text { in relation to date } \\
\text { of application }\end{array}$} \\
\hline & & $\begin{array}{c}8 \text { weeks be- } \\
\text { fore }\end{array}$ & On date & $\begin{array}{l}8 \text { weeks } \\
\text { after }\end{array}$ & $\begin{array}{l}8 \text { weeks } \\
\text { before }\end{array}$ & $\begin{array}{l}8 \text { weeks } \\
\text { after }\end{array}$ \\
\hline & & $M m$ & $M m$ & $M m$ & ${ }^{\circ} \mathrm{C}$ & ${ }^{\circ} \mathrm{C}$ \\
\hline Isabela & 1971-72 (early) & $326(9)^{1}$ & 40 & $225(2)$ & 24.9 & 23.5 \\
\hline Isabela & 1971 (late) & $313(111)$ & 22 & $390(-10)$ & 23.1 & 24.6 \\
\hline Cambalache & 1971. & 535 (344) & 13 & $259(110)$ & 24.1 & 23.7 \\
\hline Coloso & 1971 & $129(6)$ & 13 & $146(18)$ & 23.2 & 23.0 \\
\hline Igualdad & 1971 & $23(-59)$ & 0 & $127(-1)$ & 24.0 & 23.9 \\
\hline Mercedita & 1971 & $46(-47)$ & 3 & $23(-19)$ & 24.0 & 24.1 \\
\hline
\end{tabular}

${ }^{1}$ Numbers in parenthesis refer to departure from long-term means.

TABLE 3.-The influence of Polaris as a sugarcane ripener, for seasonal application, Isabela Substation, 1971-72

\begin{tabular}{|c|c|c|c|c|}
\hline \multirow[t]{2}{*}{ Polaris } & \multicolumn{4}{|c|}{$\begin{array}{c}\text { Sucrose in cane with intervals, in weeks, between application } \\
\text { and harvest }\end{array}$} \\
\hline & 2 & 4 & 6 & 8 \\
\hline Kg/ha (lb/acre) & $\%$ & $\%$ & $\%$ & $\%$ \\
\hline \multicolumn{5}{|c|}{ Beginning of harvest season } \\
\hline 0 & - & $9.23 \mathrm{a}^{1}$ & $9.23 \mathrm{a}$ & $10.06 \mathrm{a}$ \\
\hline $2.24(2)$ & - & $9.52 \mathrm{a}$ & $10.10 \mathrm{~b}$ & $10.50 \mathrm{ab}$ \\
\hline $4.48(4)$ & - & $9.85 \mathrm{a}$ & $10.29 \mathrm{bc}$ & $10.75 \mathrm{ab}$ \\
\hline $6.72(6)$ & - & $10.38 \mathrm{a}$ & $10.75, c$ & $11.08 \mathrm{~b}$ \\
\hline \multicolumn{5}{|c|}{ End of harvest season } \\
\hline 0 & $10.23 \mathrm{a}$ & $9 . .89 \mathrm{a}$ & $9.57 \mathrm{a}$ & $9.21 \mathrm{a}$ \\
\hline $2.24(2)$ & $10.25 \mathrm{a}$ & $10.13 \mathrm{ab}$ & $9.71 \mathrm{a}$ & $9.31 \mathrm{a}$ \\
\hline 4.48 (4) & $10.70 \mathrm{ab}$ & $10.14 \mathrm{ab}$ & $10.36 \mathrm{a}$ & $9.24 \mathrm{a}$ \\
\hline $6.72(6)$ & $10.92 \mathrm{~b}$ & $10.91 \mathrm{~b}$ & $10.34 \mathrm{a}$ & $9.59 \mathrm{a}$ \\
\hline
\end{tabular}

${ }^{1}$ Mean values in the columns and seasonal designation with one or more letters in common do not differ significantly at the $5 \%$ level.

the beginning of the harvest season and prevent its reduction at the end of the season in Puerto Rico.

The ratoon crop of the late-harvest experiment was examined to determine whether Polaris had residual effects on the growth of the subsequent crop. Plots receiving 0, 2.24, 4.48, and $6.72 \mathrm{~kg} /$ ha Polaris in the former crop had 5.5, 5.2, 5.9, and 5.2 canes/m of row, respectively, in the 4 -month old ratoon. No visual differences in cane vigor were de- 
tected. Similar lack of inhibition of ratoon growth after Polaris treatment has been reported for Louisiana (9).

Polaris application stimulated side-shooting of the eyes, usually within 3 to 4 weeks. For the Isabela (early-harvest) experiment the application of $0,2.24,4.48$, and $6.72 \mathrm{~kg} /$ ha produced $8.0,8.2,9.6$, and 10.4 side-shoots per stalk, respectively. The side-shoots from the 4.48 and $6.72 \mathrm{~kg} / \mathrm{ha}$ treatments were significantly greater in number than the 0 and $2.24 \mathrm{~kg} / \mathrm{ha}$ treatments.

\section{COMMERCIAL-SCALE TRIALS}

The commercial-scale trial (table 4) gave small but consistent sucrose increases. These were significant at 4 weeks after Polaris application when the north and west coast trials were grouped together.

A comparison of the commercial-scale trials with the Isabela field-plot experiment, at the beginning of harvest season (table 3), shows that the commercial-scale trials produced generally smaller responses:

\begin{tabular}{lcc}
\multicolumn{1}{c}{ Test } & Kg/ha Polaris & Relative sucrose content \\
All & 0 & 100.0 \\
Commercial & 3.36 & 103.4 \\
Isabela & 2.24 & 104.3 \\
Isabela & 4.48 & 106.9 \\
Isabela & 6.72 & 111.6
\end{tabular}

Some probable contributing factors to the small responses to Polaris by the commercial trials include: 1) The relatively late application of the commercial trials (January-February) as compared to the plot tests (mid November); 2) a more thorough application of the Polaris to the field plots by back-pack sprayers than to commercial plots by airplane (467 vs 74 liters/ha; and 3) higher Polaris rates used in the field-plot experiments.

\section{OTHER CONSIDERATIONS}

Field experiments in Puerto Rico indicate that Polaris has a potential for ripening cane under adverse maturity conditions. However, the field trials were not numerous enough nor sufficiently detailed to provide answers to the following questions:

1. What are the differences in variety responses to ripeners? PR 980, the predominant variety grown in Puerto Rico, is considered to be high tonnage, intermediate in sucrose, late maturing, and quite responsive to such growth stimuli as moisture and nitrogen. Many varieties do not have these agronomic characteristics. Workers in Louisiana and Hawaii (9) have found differences in varietal response to Polaris.

2. What is the relation of the degree of foliar wetting to ripener effectiveness? The degree of response to Polaris appears to decrease from 
greenhouse to field plots to commercial tests where volume of aqueous solution applied to the cane foliage decreases. Yet, on a per plant basis, quantities of Polaris applied are less in the greenhouse than those used in the field.

3. What is the most effective application-to-harvest interval for Polaris in relation to when it is applied in the harvest season? The limited experimental evidence in this report indicates superior sucrose responses are produced from 6 to 8 weeks after application early in the

TABLE 4.-Influence of Polaris as a ripener on commercial sugarcane fields, 1971

\begin{tabular}{|c|c|c|c|c|c|}
\hline \multirow{2}{*}{ Location } & \multirow{2}{*}{ Polaris } & \multicolumn{4}{|c|}{$\begin{array}{c}\text { Sucrose in cane with interval in weeks, } \\
\text { between application and harvest }\end{array}$} \\
\hline & & 2 & 4 & 6 & 8 \\
\hline & Kg/ha (lb/acre) & $\%$ & $\%$ & $\%$ & $\%$ \\
\hline \multicolumn{6}{|l|}{ Humid northcoast } \\
\hline \multirow[t]{2}{*}{ Cambalache } & 0 & 6.31 & 5.93 & 7.13 & 7.89 \\
\hline & $3.36(3)$ & 6.32 & 6.80 & 7.21 & 7.98 \\
\hline \multirow[t]{2}{*}{ Coloso } & 0 & 9.51 & 9.59 & 11.21 & 11.61 \\
\hline & $3.36(3)$ & 9.48 & 10.45 & 11.38 & 12.23 \\
\hline \multirow[t]{2}{*}{ Igualdad } & 0 & 7.63 & 6.68 & 8.88 & 9.54 \\
\hline & $3.36(3)$ & 5.77 & 7.70 & 9.17 & 9.41 \\
\hline \multirow[t]{2}{*}{ Average northcoast } & 0 & 7.82 & 7.40 & 9.07 & 9.68 \\
\hline & $3.36(3)$ & 7.19 & $8.32^{* 1}$ & 9.25 & 9.87 \\
\hline \multicolumn{6}{|l|}{$\begin{array}{l}\text { Irrigated southcoast } \\
\text { Mercedita }\end{array}$} \\
\hline \multirow[t]{2}{*}{ PR 980} & 0 & 10.14 & 11.57 & 12.22 & 12.08 \\
\hline & $3.36(3)$ & 10.93 & 12.17 & 12.65 & 13.54 \\
\hline \multirow[t]{2}{*}{ B $49-119$} & 0 & 9.34 & 10.19 & 11.82 & 11.67 \\
\hline & $3.36(3)$ & 10.07 & 10.39 & 12.21 & 11.83 \\
\hline \multirow[t]{2}{*}{ Average southcoast } & 0 & 9.74 & 10.88 & 12.02 & 11.86 \\
\hline & $3.36(3)$ & 10.50 & 11.28 & 12.43 & 12.69 \\
\hline \multirow[t]{2}{*}{ Average all trials } & 0 & 8.59 & 8.83 & 10.23 & 9.35 \\
\hline & $3.36(3)$ & 8.51 & $9.46^{*}$ & 10.39 & 9.63 \\
\hline
\end{tabular}

* Significant at the $5 \%$ level.

harvest season but at 2 to 4 weeks late in the season in field plot tests and at 4 weeks early in the season in commercial scale tests.

Although the field work in Puerto Rico (1971-72) indicates a ripening potential from Polaris application, the magnitude of such responses in the individual experiments varied from 7 to $17 \%$ when significant increases in sucrose were obtained. Additional research work is needed to determine the conditions which will allow for a greater efficiency in commercial usage.

The economic aspects of the use of Polaris indicate that, at an estimated price of $\$ 15 / \mathrm{kg}$ and $\$ 8$ for cost of application, on cane of 90 tons $/$ ha and an assumed sugar price of $\$ 200 / t$, the use of $6.72 \mathrm{~kg} / \mathrm{ha}$ could produce a profit of approximately $\$ 97, \$ 171$, and $\$ 75 /$ ha when harvesting the cane at 4, 6, and 8 weeks after application for the beginning of the 
harvest season under conditions similar to those in the field-plot experiment at Isabela. For late season application, at the same rate and prices, a profit of $\$ 15, \$ 75, \$ 30$, and $\$ 40 /$ ha could have been realized when harvesting at $2,4,6$, and 8 weeks after Polaris application.

The commercial-scale tests suggest increased profits of from $\$ 96$ to $\$ 104 /$ ha, at harvest 4 weeks after application of $3.36 \mathrm{~kg} / \mathrm{ha}$ of Polaris on the humid north and west coast using the same estimated costs and prices.

\section{RESUMEN}

El agente químico madurativo de la caña de azúcar, Polaris, [N, N-bis (phosphonomethyl) glycine], se evaluó, en pequeñas parcelas repetidas y en pruebas comerciales para determinar las cantidades óptimas y la época de aplicación más apropiada. En el experimento de parcelas repetidas, donde se aplicó el Polaris al comienzo de la cosecha (enero-febrero), se encontró que aplicaciones de $2.24,4.48$ y $6.72 \mathrm{~kg}$./ /ha. aumentaron significativamente el contenido de sacarosa en caña y sobre el testigo sin tratar, en muestras tomadas 6 semanas después de aplicado el producto. La aplicación de $6.72 \mathrm{~kg}$./ ha. aumentó significativamente el contenido en sacarosa sobre la de $2.24 \mathrm{~kg}$./ha. Luego de 8 semanas de aplicado el Polaris, solamente la aplicación de $6.72 \mathrm{~kg}$./ha. produjo aumentos significativos sobre el testigo sin tratar.

Aplicado en las postrimerías de la zafra (mayo-junio), a razón de $6.72 \mathrm{~kg}$./ha. evitó en forma significativa reducciones en el contenido en sacarosa en muestras tomadas a las 2 y 4 semanas, pero no tuvo efecto significativo a las 6 y 8 semanas. La aplicación a razón de $6.72 \mathrm{~kg}$./ha, al comienzo de la cosecha causó un aumento medio de $12.9 \%$ con un contenido en sacarosa (10.74 vs 9.51) sobre el testigo, mientras que el correspondiente aumento para la aplicación tardía (mayo-junio) fue de $7.3 \%$ (10.44 vs. 9.73).

En las pruebas comerciales donde se aplicó el material a razón de $3.36 \mathrm{~kg}$./ha. por avión en la zona húmeda de la costa norte, y la costa sur bajo riego, se encontró un efecto significativo al combinar las pruebas efectuadas en la costa norte con aumentos en el contenido de sucrosa entre 9 y $15 \%$ sobre el testigo en muestras tomadas 4 semanas luego de aplicado el Polaris.

\section{LITERATURE CITED}

1. Alexander, A. G., Chemical ripening and sucrose control. Chap. 12 in: Sugarcane Physiology. Elsevier Publishing Co., Amsterdam, 1973.

2. - and Montalvo-Zapata, R., Ripening activity of CP 41845 in sugarcane having nitrate and gibberellic acid-stimulated growth regimes, Crop. Sci. 12: 654-7, 1972.

3. Bieske, G. C., Chemical ripening of sugarcane, Proc. Queensl. Soc. Sugar Cane Technol. 37: 117-24, 1970.

4. Frost, K. R., and Selleck, G. W., Sucrose enhancement with glyphosine in Louisiana sugarcane, Proc. Amer. Soc. Sugar Cane Technol. Abstracted in Sugar y Azúcar. 68(6): $28,1973$.

5. Mejía, D., Results obtained with maturity regulator MON-0845, Consejo Estatal del Azúcar, Dominican Republic, Information Bull. No. 6: 7-8, 1972.

6. Nickell, L. G., Chemical ripeners for sugarcane, Univ. Hawaii Coop. Ext. Serv. Misc. Publ. 102: 42-8, 1973.

7. Ramírez-Silva, F. J., and Rivera-Brenes, A., Establecimiento de un método directo de las cañas entregadas para molienda mediante el uso de cala mecánica (core sampler) y para el cálculo de rendimiento de las entregadas a las centrales Fajardo y Cambalache, Sección VII A-B, Informe Junta Azucarera de P.R. 15 de julio de 1970.

8. Samuels, G., Vélez, A., Yates, R. A., and Walker, B., Evaluation of chemical ripeners for sugarcane, J. Agr. Univ. P.R. 56(4): 370-96, 1972.

9. Selleck, G. W., Frost, K. R., Bellman, R. C., and Brown, D. A., Sucrose enhancement in field scale sugarcane trials with Polaris in Florida, Hawaii, and Louisiana. Proc. 15th Cong. Int. Soc. Sugar-Cane Technol.; 938-45, 1974.

10. Sookashthan, K., and Subba-Rao, L., Effect of growth regulating substances on juice quality and yield of sugarcane, Indian Sugar J. 19(1): 29-40, 1969.

11. Tianco, A. P., and Escober, T. R., Chemical ripening of sugarcane with CP 41845 , Sugar News (Nov.): 508-31, 1970.

12. Vlitos, A. J., and Lawrie, I. D., Chemical ripening of sugarcane, Proc. 12th Cong. Int. Soc. Sugar-Cane Technol., 429-45, 1965. 